Jan Stachowski

\title{
O TERMINOLOGII OSADNICTWA TURYSTYCZNEGO
}

\section{SUR LA TERMINOLOGIE DE LA COLONISATION TOURISTIQUE}

\begin{abstract}
Opracowanie prezentuje pogląd autora na temat polskiej terminologii osadnictwa, okıreślanego dziś najczęściej jako turystyczne. Po omówieniu genezy podstawowych terminów, ich budowy i znaczeń, autor postuluje uporządkowanie terminologii tego osadinictwa na osnowie systemu pojęć podstawowych z zakresu rekreacji.
\end{abstract}

\section{POCHODZENIE PODSTAWOWYCH TERMINÓW}

Nie jest rzeczą prostą odtworzenie okoliczności pojawienia się polskich terminów wskazujących osiedla, które dziś na ogół określane są jako turystyezne, a ostatnio również jako rekreacyjne. Jest bardzo prawdopodobne, że niektóre $\mathrm{z}$ nich, zwłaszcza te starsze, były wzorowane na terminach obcych, przede wszystkim niemieckich i francuskich (E. N awratil - Trybowska 1938). Młodsze są na ogół rodzimego pochodzenia. Ponieważ odtworzenie pochodzenia pełnego zbioru terminów nie było celem tej pracy, ich geneza zostanie zaprezentowana na przykładach terminów najczęściej spotykanych przy wyodrębnianiu tego osadnictwa spośród innych jego rodzajów.

Wydaje się, że najstarszymi rodzimego pochodzenia terminami sạ: "zdrojowisko" i „letnisko" (letniaki). Pojawiły się one w języku codziennym w drodze naturalnej ewolucji ich podstaw słowotwórczych tak, że nie musiały być definiowane. Pierwsze określenia $w$ formie definicji pojawiły się na początku XX w. Terminem, który zdefiniowano chyba najwcześniej było „uzdrowisko". W Polsce zostało ono zdefiniowane w 1922 r. w Ustawie o uzdrowiskach ${ }^{1}$. Ustawowe pojmowanie ,uzdro-

1 Ustawa o uzdrowiskach z 23.03.1922 r. (Dz. Ust. 1922, nr 31, poz. 254) ze zmianami i uzupelnieniami wprowadzonymi rozporządzeniem Prezydenta RP z 22.03.1928 r. (Dz. Ust. 1928, nr 36, poz. 331). 
wiska" było później na ogół akceptowane i osiedla tego rodzaju były rozpatrywane niezależnie od innych osiedli spełniających różne funkcje względem ludności przyjezdnej. Ustawa z 1922 r. traktowała termin "uzdrowisko" [17] $]^{2}$ jako ogólny. i nadrzędny dla trzech terminów szczegółowych: „zdrojowiska" - terminu w ustawie zdefiniowanego i będącego wprost synonimem uzdrowiska, „stacji klimatycznej” (terminu niezdefiniowanego) i "kąpieliska morskiego" (terminu niezdefiniowanego). Można przypuszczać, że w pojmowaniu terminów niezdefiniowanych należało się wzorować na ich obcych odpowiednikach, np. niem. "Seebäd" i "Luftkurort". Odnowiona w 1966 r. Ustawa o uzdrowiskach i leczeniu uzdrowiskowym ${ }^{3}$ zawiera nową definicję terminu „uzdrowisko" [18], nie proponując terminów względem niego podrzędnych. Niezależnie od definicji ustawowej, normy prawnej obecnie obowiązującej, termin "uzdrowisko" został zdefiniowany przez planistów [19] (J. Szuszkiewi c z i in. 1976) oraz przez geografów turyzmu [20] (J. W a rszyńska, A. Jackowski 1978). Zakresy semantyczne terminu wynikające $\mathrm{z}$ tych definicji są zbliżone.

Znaczenia kolejnych terminów, mianowicie „miejscowości turystycznej” i „miejscowości wypoczynkowej”, które były używane obok terminu „uzdrowisko" i tematycznie jemu pokrewnych, zostały również ujęte w aktach prawnych, a ściślej przedwojennych projektach ustaw: letniskowej i o miejscowościach turystycznych (S. Leszczycki 1938). Projekty tych aktów zostały opracowane przez Krakowską Izbę Przemysłowo-Handlową, a ich celem było uporządkowanie podstaw prawnych gospodarki stymulowanej ruchem letniskowo-turystycznym w osiedlach nie będących uzdrowiskami. W Projekcie ustawy letniskowej z 1934 r. znajdowały się definicje terminów „letniska” [2] i „miejscowości turystycznej” [4]. Termin "letnisko" oznaczał miejscowość, do której letnicy przybywali na pobyty dłuższe, co najmniej dwutygodniowe w sezonie letnim, natomiast termin miejscowość turystyczna odnosił się do miejscowości, w których występował ruch turystyczny, głównie wędrowny i krajoznawczy. Pojęcie "miejscowości turystycznej" w tej wersji ustawy akcentowało rozumienie wyjściowego pojęcia turystyki sensu stricto, zgodnie $\mathrm{z}$ jego etymologicznym założeniem. Propozycje Krakowskiej Izby Przemysłowo-Handlowej z niewielkimi zmianami były przyjęte przez Krajową Komisję Turystyczną Związku Izb Przemysłowo-Handlowych. Wymieniona Komisja zaproponowała po-

${ }^{2}$ Definicje omawianych terminów zamieszczono w słowniku terminów załączonym na końcu tekstu. Podana liczba w nawiasie klamrowym określa pozycję terminu w słowniku.

3 Ustawa o uzdrowiskach i leczeniu uzdrowiskowym z 17.06 .1966 r. (Dz. Ust. 1966, nr 23, poz. 150). 
dział wszystkich osiedli odznaczających się występowaniem ruchu letniskowo-turystyczno-uzdrowiskowego na trzy grupy: uzdrowiska (zgodnie $\mathrm{z}$ ustawą uzdrowiskową), miejscowości wypoczynkowe i miejscowości turystyczne. Pojęcie „miejscowości wypoczynkowej” odpowiadało pojęciu „letniska”, natomiast pojęcie „miejscowości turystycznej” nawiązywało do jego znaczenia w projekcie krakowskim, którego zakres uzupełniono o działalności sportowe (M. Fularski 1935). Jak donosi S. Leszczycki (1939), w 1938 r. zaproponowano nową definicję „miejscowości wypoczynkowej”. Nawiązywała ona do poprzednich, lecz swym zakresem obejmowała nie tylko "letniska", ale także miejscowości „,czynne" w sezonie zimowym, czyli "zimowiska" [9].

Warto podkreślić, że przedwojenne definicje osiedli związanych z ruchem wypoczynkowo-turystycznym formułowane były głównie z punktu widzenia prawno-administracyjnego. Stąd też były to typowe definicje nominalne, projektujące, czyli proponujące określony sposób pojmowania, a przede wszystkim identyfikowania takich osiedli. W treści tych definicji, obok ogólnych cech opisowych, występowała na ogół jedna cecha ściśle wyznaczająca zakres znaczeniowy terminu.

Terminy $\mathrm{i}$ ich znaczenia $\mathrm{z}$ okresu międzywojennego, zarówno te 7 clefiniowane, jak i te przyjmowane na zasadzie obyczaju językowego, zostały bez większych zmian przyjęte w pierwszych latach powojennych (np. J. Kostrowicki 1952).

W $1960 \mathrm{r}$. w związku z wyraźnym rozwojem ruchu turystycezno-wypoczynkowego, instytucji i organizacji z nim związanych, wzrustem inwestycji turystyczno-wypoczynkowych, powołano do życia państwowy organ dla administrowania sferą turystyki i wypoczynku w skali kraju - Główny Komitet Kultury Fizycznej i Turystyki. Działalnością Komitetu w zakresie turystyki zostały objęte wszystkie formy aktywności turystyczno-wypoczynkowej zarówno indywidualne, jak i zbiorowe. W aktach prawnych Komitetu pojęcie „turystyka” stosowane było w nowym, rozszerzonym zakresie znaczeniowym - sensu largo. Można przypuszczać, że $\mathrm{u}$ podstaw rozszerzonego pojmowania tego terminu legła, zaakceptowana przez GKKFiT, definicja "turysty" - przyjęta przez Międzynarodowy Związek Oficjalnych Organizacji Turystycznych. W 1965 r. Prezydium GKKFiT podjęło uchwałę zawierającą prawno-administracyjną definicję terminu "miejscowośé turystyczna" [5], sformułowaną dla potrzeb planowania przestrzennego, kierowania ruchem turystycznym i propagandy turystycznej. Zdefiniowany termin ,miejscowość turystyczna" przyjęty był jako nadrzędny względem podrzędnych: "miejscowości turystycznej o charakterze wypoczynkowym",

4 Uchwała Prezydium Glównego Komitetu Kultury Fizycznej i Turystyki z 04.02. 1965 r., nr 5/65. 
„miejscowości turystycznej o charakterze krajoznawczym” i „miejscowości turystycznej o charakterze wypoczynkowo-krajoznawczym". Wspomniana uchwała oficjalnie ustaliła urzędowy słownik terminologiczny omawianego osadnictwa dotyczący 4 terminów. Znalazły się one $\mathrm{w}$ powszechnym użyciu w słownictwie administracji państwowej, organizacji turystycznych i informacji turystycznej. Stosunkowo szybko stały się zwyczajem językowym, wypierając z obiegu terminy starsze.

Nazewnictwo administracji państwowej, słownictwo języka potocznego, nie znalazło aprobaty u planistów przestrzennych. W ich opinii, było ono mało precyzyjne, stąd mało przydatne dla sporządzania założeń i dokumentacji projektowo-kosztorysowych planów przestrzennego zagospodarowania (J. Szuszkiewicz 1966). Dlatego też od samego początku wraz z objęciem zagospodarowania służącego turystyce i wypoczynkowi planowaniem przestrzennym, środowisko urbanistów i architektów podjęło prace nad uściśleniem odnośnej terminologii (J. S z uszki ewicz, B. Kasperski i Z. H enclik 1964). W szczególności należy zauważyć, że środowisko planistów nie zaakceptowało pojęcia „turystyka" sensu largo. Jako pojęcie podstawowe i nadrzędne przyjmowało ono pojęcie ,rekreacja", a w odniesieniu do osadnictwa terminy „osadnictwo rekreacyjne" i ,jednostka osadnicza związana z rekreacją". W 1962 r. w Pracowni Zagadnień Rekreacji Instytutu Urbanistyki i Architektury opracowano podział jednostek osadniczych według stopnia powiązania z rekreacją. W jego ramach pojawiły się sformułowania: „,jednostki osadniczej w pełni powiązanej z rekreacją" (3 typy według stopnia rozwoju funkcji wypoczynkowo-letniskowych, turystycznych lub uzdrowiskowych, wyposażenia mającego związek z rekreacją, walorów zdrowotnych i krajobrazowych), ,,jednostki osadniczej częściowo powiązanej z rekreacją", jednostki osadniczej w zasadzie nie związanej z rekreacją i miejscowości o charakterze turystyczno-wypoczynkowym nie będącej jednostką osadniczą (J. Szuszkiewicz, B. Kasperski i Z. Henclik 1964). W 1976 r. J. Szuszkiewicz wraz z zespołem opublikowali system terminologiczny dla potrzeb osadnictwa i budownictwa rekreacyjnego. Jest on podsumowaniem prac Komisji Nazewnictwa Sekcji Zagospodarowania Rekreacyjnego TUP i zarazem wykładnią poglądów środowiska planistów przestrzennych dotyczących terminologii tego osadnictwa. Pojęciem podstawowym $w$ tym systemie jest pojęcie „miejscowości rekreacyjnej” [3], a także [6, 8 i 19]. W odniesieniu do terminologii związanej z planowaniem przestrzennym wypada zauważyć dokonania L. A. D ę bs ki e go (1974, 1975 i 1977). Wymieniony autor preferujący jako ogólny termin "osadnictwo wczasowe", proponuje szereg nowych terminów szczegółowych, często wzorowanych na ich obcych odpowiednikach, jak np. „wioska wakacyjna”, „mega- 
struktura wczasowa”, ,aglomeracja wczasowa”: „zwarta”, „,rozproszona”, „łańcuchowa” itd.

Pierwszą wykładnię polskiej terminologii geograficznej związanej $\mathrm{z}$ osadnictwem turystycznym przedstawili geografowie turyzmu J. Warszyńska i A. J a ckowski (1978). W ujęciu tych autorów osiedla turystyczne reprezentują jedną $\mathrm{z}$ dwóch kategorii turystycznych jednostek przestrzennych. Pojęciem podstawowym w kategorii osadniczych jednostek przestrzennych jest pojęcie i termin „miejscowość turystyczna" [7]. Jest ona pojęciem ogólnym i nadrzędnym względem zbioru terminów jej podrzędnych, rozróżnionych przez stosowanie różnych kryteriów w zestawienia zbliżone do typologii. Większość wykazanych terminów znana jest $\mathrm{w}$ języku potocznym, stąd też tylko niektóre $\mathrm{z}$ nich, te rzadziej spotykane i używane zostały zdefiniowane. W definicje zostały wyposażone takie terminy jak: „wieś turystyczna”, „letniskowa”, ,zimowiskowa” [25], „kąpielisko morskie” [20], „stacja klimatyczna" [20], „stacja sportów zimowych" [16], „ośrodek turystyczny" (,wypoczynkowy”, „krajoznawczy”, „sportowy”, „wypoczynku świątecznego") [13].

Termin „ośrodek" z odpowiednim określeniem jest terminem często spotykanym w nazewnictwie różnych form przedmiotowego osadnictwa. Jako pierwszy użył tego terminu w latach trzydziestych M. Fulars k i (1935). Proponował on termin "ośrodek atrakcyjności turystycznej" jako najogólniejsze określenie miejscowości $z$ funkcją uzdrowiskowo-letniskowo-turystyczną. W czasach powojennych termin „ośrodek" z odpowiednim, przymiotnikowym określeniem stosowany był $\mathrm{w}$ dwóch znaczeniach. Jako synonim terminu „miejscowość”, „osiedle”, ,jednostka osadnicza", oraz jako nazwa pojęcia oznaczającego na ogół domknięty pod względem organizacyjno-funkcjonalnym obiekt służący określonej formie rekreacji, np.: „ośrodek wczasowy”, „ośrodek sportowy”, „ośrodek wypoczynku świątecznego" [12-14]. Z punktu widzenia etymologii użycie drugiej wersji nazwy jest słuszniejsze, bowiem podkreśla jednoznaczność funkcji punktu geograficznego tak określanego. Używanie tego terminu jako synonimu "osiedla", „jednostki osadniczej" winno mieć zastosowanie ograniczone tylko do osiedli monofunkcyjnych. Na ogół jednak tego rodzaju wyznacznik zakresu terminu „ośrodek" nie jest brany pod uwagę.

Obok terminów odnoszących się do pojedynczych osiedli, pojawiły się terminy odnoszące się do zespołów, zgrupowań takich osiedli. Przeważnie są one nazwami projektowanych struktur przestrzennych osadnictwa rozwijającego się pod wpływem rekreacji. Na początku lat sześćdziesiątych w Wojewódzkiej Pracowni Urbanistycznej w Gdańsku sformułowano pojęcie ,zespołu (nadmorskich) miejscowości rekreacyjnych" 
[27] (H. Gur janow a 1975). W 1975 r. L. A. D ę bs k i wysunął koncepcję „układu osadniczego wczasowego", natomiast A. Romiszews k i (1983) „zespołu osadniczego rekreacyjnego" [28]. Podobnych tematycznie terminów proponowanych przez planistów przestrzennych można by wymienić więcej.

W dotychczasowych rozważaniach nie wymieniano terminologii, której źródłem były badania geograficzno-osadnicze. Niestety, dość długo problematyka turystyki, wypoczynku czy rekreacji traktowana była w tej dyscyplinie geografii wręcz marginalnie. W nielicznych opracowaniach znajdujemy terminy powszechnie znane, o których wzmiankowano wyżej. Pewną ilustracją stanu terminologii osadnictwa turystycznego w geografii polskiej na początku lat siedemdziesiątych było wręcz symboliczne jej zaprezentowanie na sympozjum poświęconym terminologii w geografii turyzmu, zorganizowanym przez Grupę Roboczą Geografii Turyzmu MUG w 1974 r. w Krakowie i Zakopanem (Zagadnienia terminologii.. 1976). Dopiero w latach siedemdziesiątych, a zwłaszcza osiemdziesiątych osadnictwo związane $\mathrm{z}$ turystyką i rekreacją stało się przedmiotem szerszego zainteresowania profesjonalnych geografów osadnictwa. Prowadzone przez nich badania winny zaowocować również rezultatami w dziedzinie terminologii.

\section{BUDOWA I ZNACZENIA TERMINOW}

Większość terminów dotyczących osadnictwa turystyeznego używanych obecnie jest terminami złożonymi, występującymi w zestawieniach dwu- a nawet trzywyrazowych. W początkowym okresie w powszechnym użyciu były terminy jednowyrazowe - monotematyezne jak: , letnisko”, „zdrojowisko”, „kąpielisko”, „wczasowisko”, „zimowisko”. Są to rzeczowniki odczasownikowe, utworzone przez dodanie do formantus określającego nazwę czynności lub przedmiot (środowisko) wywołujące czynność, sufiksu -isko. Niektóre spośród wymienionych terminów znajdują się nadal w użyciu, inne używane są rzadziej i raczej w mowie potocznej.

W zestawieniach dwuwyrazowych pierwszy wyraz odnosi się do obiektu osadniczego jako takiego i wyrażany jest przez takie terminy jak: „miejscowość”, „ośrodek”, „wieś" i „miasto”, rzadziej ...ednostka osadnicza"; termin występuje na ogól w definicjach. w ich definiensie jako nazwa rodzaju. Przytoczone terminy traktowane są jako synonimy, czasami jednak w znaczeniu wskazującym konkretny desygnat gatunko.

\footnotetext{
5 Formant - część terminu będąca jego podstawą słowotwórczą i semantyczną (przyp, autora).
} 
wy, co wynika ze znaczenia całego zestawienia. Drugi wyraz terminu zestawionego jest przymiotnikowym określeniem wyrazu pierwszego jak: „rekreacyjna” (miejscowość), „wypoczynkowy” (ośrodek), „letniskowa” (wieś) itp. Funkcją tych przymiotników wyrażających treści semantyczne określone przez ich podstawy słowotwórcze jak: rekreacja, turysty ka, wypoczynek itd. jest ustalenie znaczenia całego zestawienia.

Spotkać można także terminy będące zestawieniami trzywyrazowymi, w których obok wyrazu oddającego gatunek obiektu osadniczego, wyrazu określającego ogólny charakter tego obiektu, występuje trzeci wyraz akcentujący wybraną cechę szczegółową. Wyrazy te oddają najczęściej wielkość, rangę, stopień rozwoju itp. Są to na przykład określenia w rodzaju ,mały”, „duży” itd., „lokalny”, „regionalny” itd., „słabo rozwinięty", "rozwijający się" itd. Powyższy człon w takich zestawieniach jest na ogół wyznacznikiem podgatunku w ramach formalnych klasyfikacji obiektów osadniczych danego gatunku.

Z zarysowanej wyżej genezy zbioru terminów odnoszących się do omawianego osadnictwa wynika, że terminem najczęściej stosowanym dla określenia jego charakteru i wyróżnienia go w sieci osadniczej jest przymiotnik turystyczne - osadnictwo turystyczne. Określenie to jest pochodnym od podstawy słowotwórczej turystyka sensu largo, tzn. pojęcia obejmującego liczne zachowania i działalności ludzi związane z odnową sił psychofizycznych i zaspokajaniem niektórych potrzeb poznawczych jednostek. Stąd też podstawowym terminem odnoszącym się do pojedynczego osiedla jest termin miejscowość turystyczna. Pierwotnie termin ten dotyczył osiedla związanego $\mathrm{z}$ turystyką w etymologicznie uzasadnionym rozumieniu, tj. turystyką ograniczoną do form wędrownych, przyjemnościowo-krajoznawczych. Zmiana natury pojęcia turystyka, przypisywanie mu dwóch znaczeń, bywa istotnym źródłem trudności w porozumiewaniu się. Unikają tych trudności urbaniści i architekci przyjmujący termin „turystyka” w jego pierwotnym znaczeniu i uznający osadnictwo turystyezne jako jedną $z$ form osadnictwa rekreacyjnego, pojęcia stosowanego przez nich jako najbardziej ogólnego dla określenia omawianego osadnictwa. Nierzadko praktykowane jest stosowanie określeń „turystyczne” i „rekreacyjne” jako określeń bliskoznacznych czy wręcz jednoznacznych.

Zmiany znaczeń oraz funkcji w języku dotyczą także innych terminów, chociaż mogą w tym względzie występować różnice regionalne. Wydaje się, iż coraz rzadziej spotykany jest termin „letnisko" [2], który zastępuje się terminem "wieś letniskowa" [21, 22], a także terminami „wieś turystyczna” [24, 25] lub „wieś rekreacyjna” [23]. Przymiotnik „letniskowy” jest dziś częściej kojarzony z prywatnym domkiem letniskowym aniżeli osiedlem letniskowym w jego tradycyjnym znaczeniu. 
Także termin „zimowisko”, pierwotnie kojarzony z miejscowością wypoczynkową odwiedzaną w sezonie zimowym, jest dziś terminem odnoszącym się do formy organizacyjnej wypoczynku młodzieży w sezonie zimowym. Wspomniano już wyżej o zmianie znaczeń określeń przymiotnikowych w terminach będących zestawieniami, w zależności od treści pojęcia wyrazu określanego, np. „miejscowość wczasowa” i „ośrodek wczasowy" (zakładu pracy).

Cechą charakterystyczną wielu omawianych terminów jest ich semantyczna nieostrość. Stąd liczne spośród nich funkcjonują jako svnonimy, np.: "miejscowość turystyczna" = "miejscowość rekreacyjna", „wieś letniskowa” = „wieś turystyczna” = „wieś rekreacyjna”, „miejscowość wypoczynkowa" = „miejscowość wczasowa” itd. Łatwość mnożenia synonimów wynika nie tylko z nieostrości określeń przymiotnikowych, ale również $\mathrm{z}$ traktowania jako synonimów terminów odnoszących się do obiektów osadniczych, np.: "miejscowość turystyczna" = „ośrodek turystyczny”, „miejscowość letniskowa” = „wieś letniskowa” itd.

Nieostrość zakresów semantycznych terminów odnoszących się do omawianego osadnictwa, będąca ich oczywistą wadą, była i jest dostrzegana. Podejmowane były także liczne próby jej usunięcia, zauważalne zwłaszcza $\mathrm{w}$ projektach definicji formułowanych $\mathrm{w}$ okresie międzywojennym. Obecnie jedynym przykładem skutecznego uściślenia zakresu terminu nieostrego jest rozwiązanie przyjęte w ustawowej definicji terminu „uzdrowisko”. Definicja ta umożliwia jednoznaczną identyfikację desygnatów, czyli osiedli będących uzdrowiskami spośród osiedli, które nimi nie są. W odniesieniu do innych terminów uściślenia ich zakresów nie są znane. W geografii osadnictwa znany jest inny sposób eliminacjí nieostrości pojęć. Polega on na zastępowaniu cech opisowo określających zakres pojęć, cechami ujmującymi go wymiernie, tzn. cechami umożliwiającymi jego wyznaczenie poprzez ustalenie przedziałów ich zmienności właściwych dla istoty pojęć. Niestety, jak dotąd nie ma propozycji definicji pojęć odnoszących się do omawianego osadnictwa, które zawierałyby cechy łatwo mierzalne i których przedziałów zmienności można by użyć jako wyznaczników ich zakresów semantycznych ${ }^{6}$.

W świetle powyższego niezbędną na dziś podstawą dla rozumienia się w kwestiach dotyczących osadnictwa turystycznego jest założenie wspólnoty intuicji znaczeniowych (i poznawczych) osób porozumiewających się. Odwołują się do niej liczni autorzy i mówcy, którzy używając omawianych wyżej terminów nie podają ich znaczeń.

- Próbą w tym kierunku jest interesujące studium A. Jackowskiego (1981) kwalifikujące miejscowości turystyczne $\mathrm{z}$ punktu widzenia wymiernego zróżnicowania spełnianych przez nie funkcji turystycznych. 


\section{WNIOSKI I POSTULATY}

Intencją, która wywołała autora do niniejszej wypowiedzi, był zamiar zwrócenia uwagi na potrzebę „usprawnienia” słownika terminologicznego przedmiotowego osadnictwa. Przez usprawnienie rozumie się tu wszelkie działania $\mathrm{w}$ sferze terminologii ułatwiające wzajemną komunikację i prowadzące do lepszego porozumienia. Usprawnienie omawianej terminologii staje się szczególnie ważne dziś, wobec szerokiego zainteresowania geografów problematyką tego osadnictwa. Istotną bowiem determinantą efektywnego wkładu badaczy $w$ dziele jego poznania jest przyjmowanie przez nich w miarę jednolitego, logicznie spójnego systemu pojęciowo-terminologicznego.

Jak ukazano wyżej, terminologia przedmiotowego osadnictwa ukształtowała się głównie poza geografią, chociaż nie bez udziału geografów. Jest ona dość zasobna, niemniej jest to zasobność raczej pozorna. Wynika bowiem $\mathrm{z}$ wielości terminów bliskoznacznych, synonimów i quasi-synonimów, licznych kombinacji zestawien podobnych tematyeznie wyrażeń. Wielość terminów odnosi się niestety do stosunkowo ograniczonej liczby pojęć i to raczej ogólnych. Są one rezultatem twórczości terminologicznej pochodnej od co najmniej dwóch systemów pojęć podstawowych i słowotwórczych dla terminów odnoszących się do osadnictwa. Pozorne bogactwo terminów bliskoznacznych, a także wieloznacznych, różnie usytuowanych względem systemów pojęć podstawowych, stanowi dziś znaczne utrudnienie $\mathrm{w}$ porozumiewaniu się.

Postulując uporządkowanie tej terminologii nie zgłaszam propozycji w rodzaju: ten termin usunąć, a tamten pozostawić. Wnioskuję natomiast porządkowanie jej na podstawie jednolitego systemu pojęć i terminów podstawowych, swoistego filtru logicznego, eliminującego terminy niesłuszne, pozostawiającego słuszne i wywołujące nowe. Proponuję dla tego celu przyjęcie systemu opierającego się na pojęciu ",rekreacji", jako najbardziej ogólnym i nadrzędnym względem licznych pojęć jemu podrzędnych jak: „turystyka”, „sport”, „wczasy”, „rozrywka” itd. (M. D r z ewiecki 1983). Wieloznacznie dziś rozumiany termin ,turystyka", w systemie tym występuje tylko w jednym etymologicznie uzasadnionym znaczeniu. Takie usytuowanie i pojmowanie terminu „turystyka" eliminuje jako niesłuszne terminy pochodne, w rodzaju „ośrodek turystyki pobytowej" dla nazwania miejscowości, w której dominuje rekreacja w postaci wielodniowych pobytów, nie uzasadnia nazywania osiedla zabudowanego drugimi domami, osiedlem turystycznym itp. Opowiadam się zatem za studiowaniem przez geografów osadnictwa rekreacyjnego, jako jednego $\mathrm{z}$ jego rodzajów osadnictwa turystycznego, 
ale również wczasowego, sportowego itp. Przebudowa i budowa omawianej terminologii jako pochodnej od systemu opierającego się na nadrzędnym pojęciu rekreacji, zapewniłaby geografom łatwą komunikację ze środowiskiem planistów przestrzennych, co leży w interesie obu stron.

Powyższą wypowiedź traktuję jako głos w dyskusji na temat, który moim zdaniem wymaga i musi się stać przedmiotem takowej, jeżeli chcemy dokonać efektywnego kroku naprzód.

\section{SEOWNIK TERMINOW}

W słowniku zamieszczono terminy, na które powoływano się w tekście powyżej (cyfry w nawiasach klamrowych) i których znaczenie udało się ustalić poprzez odnalezienie ich definicji autorskich.

[1] Kąpielisko morskie - patrz hasło [20].

[2] Letnisko - miejscowość o atrakcyjności turystycznej, w której na pobytach dwutygodniowych $\mathrm{w}$ okresie sezonu turystycznego przebywało powyżej 200 osób, a jednocześnie dysponująca odpowiednimi pomieszczeniami dla przyjęcia turystów oraz charakteryzująca się dobrą dostępnościa komunikacyjną (według projektu ustawy letniskowej Krakowskiej Izby Przemysłowo-Handlowej, M. F ula r ski 1935).

[3] Miejscowość rekreacyjna - przeważnie jednostka osadnicza, która $\mathrm{z}$ racji walorów zdrowotnych, przyrodniczo-krajobrazowych bądź krajoznawczych występujących również w jej najbliższym otoczeniu, a także swego zainwestowania, skupia różne formy ruchu rekreacyjnego (według: J. Szuszki ewicz i in. 1976, s. 145).

[4] Miejscowość turystyczna I - miejscowość o walorach turystycznych (przyrodniczych lub pozaprzyrodniczych), w której rozwija się przede wszystkim turystyka krajoznawcza. W zmodyfikowanej wersji tej definicji występuje uzupełnienie jej treści wskazówka, iż miejscowość taka spełnia także funkcje sportowe (według projektu Krakowskiej Izby Przemysłowo-Handlowej ze zmianami Komisji Turystycznej Izb Przemysłowo-Handlowych w Polsce, M. F u larski 1935).

[5] Miejscowość turystyczna II - jako..., może być uznane miasto, osiedle lub wieś, będące lub mogące się stać ośrodkiem docelowym ruchu turystycznego, wypoczynkowego lub krajoznawczego ze względu na walory turystyczne: środowiska przyrodniczego, obiektów historycznvch, zabytków, przejawów tradycyjnej kultury ludowej, przejawów wspólczesnej gospodarki i kultury. Miejscowość turystyczna może mieć charakter wypoczynkowy, krajoznawczy i krajoznawczo-wypoczynkowy (według: Uchwała Prezydium GKKFiT nr 5/65, z 04.02.1965 r.).

[6] Miejscowość turystyczna III - to miejscowość rekreacyjna, w której dominują wartości poznawcze. Każda jednostka osadnicza lub 
miejscowość, która ze względu na swe wartości przyrodnicze, zabytków kultury, względnie współczesnych osiągnięć, zwłaszcza technicznych lub gospodarczych, stanowić może przedmiot zainteresowań krajoznawczych i cel wędrówek turystycznych (według: J. Sz uszki ewicz i in. 1976, s. 146).

[7] Miejscowość turystyczna IV - to jednostka osadnicza (miasto, osiedle, wieś), która ze względu na walory turystyczne, infrastrukturę turystyczną i dostępność komunikacyjną, stanowi punkt docelowy lub etapowy migracji turystyeznych (według: J. Warszyńska, A. J a ckowski 1978 , s. 31 ).

[8] Miejscowość wczasowa - miejscowość rekreacyjna o występującej funkcji wypoczynku pobytowego. Jednostka osadnicza lub miejscowość przeważnie o znacznych walorach przyrodniczo-krajobrazowych, w której występują pobyty wypoczynkowe, zorganizowane bądź indywidualne i która jest odpowiednio zagospodarowana i przystosowana do obsługi wczasowiczów (według: J. Sz u szkiewi c z i in. 1976, s. 146).

[9] Miejscowość wypoczynkowa I - każda miejscowość o charakterze letniska lub zimowiska, obu łącznie, w której w okresie ostatnich trzech lat przyjazdy o charakterze pobytowym przekraczały w każdym roku 200 osób (według: S. Leszczy c ki 1939, s. 32).

[10] Miejscowość wypoczynkowa II - patrz hasło [5].

[11] Miejscowość wypoczynkowa III - to jednostka osadnicza o funkcji wypoczynkowej, zabudowana ośrodkami wypoczynkowymi, występująca $\mathrm{w}$ zespole innych takich miejscowości w obrębie rejonu wypoczynkowego (na podstawie definicji rejonu wypoczynkowego według O. Rogalewskiego 1974, s. 75).

[12] Ośrodek rekreacyjny - miejscowość związana z bezpośrednią obsługą ruchu rekreacyjnego o udziale funkcji rekreacyjnych $\mathrm{w}$ stopniu wiodącym (według: A. R o m is z e w sk i 1983, s. 86).

[13] Ośrodek turystyczny, wypoczynkowy, krajoznawczy, sportowy itp. - miejscowość turystyczna charakteryzująca się wysokim stopniem zagospodarowania turystycznego i dysponująca szerokim profilem usług związanych z obsługą ruchu turystycznego, w której funkcja turystyczna ma charakter przewodni (według: J. W arszyńska, A. J a ckow ski 1978, s. 32).

[14] Ośrodek wypoczynku świątecznego - teren o walorach turystycznych, związany $\mathrm{z}$ większą aglomeracją miejską, położony w jej granicach lub zasięgu podmiejskiej strefy rekreacyjnej, wyposażony w podstawowe urządzenia usługowe, wypoczynkowe i rozrywkowe, przeznaczony głównie dla wypoczynku świątecznego lub w dni wolne od pracy (według: J. Warszyńska, A. Ja ck ow sk i 1978, s. 32).

[15] Stacja klimatyczna - patrz hasło [20]. 
[16] Stacja sportów zimowych - miejscowość turystyczna położona $\mathrm{w}$ terenie górskim, posiadająca korzystne warunki klimatyczne i odpowiednie zagospodarowanie turystyczne, dzięki czemu możliwe jest uprawianie sportów zimowych (według: J. Warszyńska, A. J a ck ow sk i 1978 , s. 32 ).

[17] Uzdrowisko I - za uzdrowiska uważać należy: 1) miejscowości posiadające cieplice lub zdroje lecznicze (źródła, studnie lub otwory wiertnicze o wodzie zawierającej mineralne, gazowe lub inne składniki, względnie wykazujące specjalne działania, co nadaje jej własności i zastosowanie lecznicze) czyli tzw. zdrojowiska, 2) stacje klimatyczne, 3) kąpieliska morskie (według: Ustawa o uzdrowiskach z 23.03 .1922 r.).

[18] Uzdrowisko II - miejscowość (miasto, osiedle, gromada lub część gromady), która ma warunki niezbędne do prowadzenia lecznictwa uzdrowiskowego, może być uznana przez Radę Ministrów za uzdrowisko (jest to tzw. uzdrowisko statutowe). Uzdrowisko w rozwoju określenie zwyczajowe w stosunku do miejscowości, na którą Rada Ministrów rozciągnęła niektóre przepisy dotyczące uzdrowiska (według: Ustawa o uzdrowiskach $i$ leczeniu uzdrowiskowym z 17.06 .1966 r.).

[19] Uzdrowisko III - miejscowość rekreacyjna o dominującej funkcji leczniczej. Jednostka osadnicza lub miejscowość, w której występuje zespół naturalnych warunków leczniczych i walorów zdrowotnych środowiska przyrodniczego, a także wyposażona w zakłady umożliwiające prowadzenie lecznictwa uzdrowiskowego (według: J. S z u s z$\mathrm{k}$ i e w i c z i in. 1976, s. 146).

[20] Uzdrowisko IV - miejscowość turystyczna, na terenie której prowadzi się działalność leczniczą dzięki występującym walorom balneoklimatycznym lub klimatycznym, przy równoczesnym wyposażeniu w niezbędne urządzenia. Zależnie od zespołów (walorów leczniczych) dzielą się na: zdrojowiska, w których leczy się za pomocą wód lub gazów leczniczych, kąpieliska morskie $\mathrm{z}$ wykorzystaniem leczniczych właściwości morza i stacje klimatyczne wykorzystujące właściwości lecznicze klimatu (według: J. Warszyńska, A. Jackowski 1978, s. 32 ).

[21] Wieś letniskowa I - miejscowość typu wiejskiego, małomiasteczkowego, posiadająca walory wypoczynkowe środowiska przyrodniczego, nie wyposażona jednak w żadne obiekty i urządzenia zarówno noclegowo-żywieniowe, jak i towarzyszące. W sezonie letnim sa one odwiedzane przez ludność (rodziców z dziećmi) wykorzystującą kwatery prywatne, ogólnodostępne gospody, sklepy i usługi ludności miejscowej (według: O. R o g a l e w sk i 1974, s. 78).

[22] Wieś letniskowa II - miejscowość wiejska o walorach klimatycznych, krajobrazowych, w których występuje głównie jedna forma 
rekreacji - wypoczynek pobytowy, oparta na wykorzystaniu kwater prywatnych miejscowej ludności. Funkcja rekreacyjna rzadko stanowi jedyne źródło utrzymania ludności, przeważnie jest źródłem równorzędnym lub uzupełniającym (według: B. Treśniowska 1981, s. 103).

[23] Wieś rekreacyjna I - pojęcie, które może dotyczyć tradycyjnej wsi rolniczej, która zaczyna również pełnić funkcje wypoezynkowe poprzez wynajem kwater, wykupywanie terenów i adaptowanie ich do nowych funkcji. Także - samoistny, nowo zainwestowany, niewielki ośrodek rekreacyjny, przetykany zielenią o regionalnej architekturze (według: W. Ko s ińs ki 1981, s. 101).

[24] Wieś turystyczna I - wieś posiadająca znakomite warunki naturalne dla rozwoju różnorodnych form rekreacji. Warunki te dziela się na grupy 1) niezbędne jak: rzeki, jeziora, zalesienie, klimat itp., 2) uatrakcyjniające jak: zabytki kultury, pomniki przyrody, wartośei folkloru itp., ponadto odpowiednie usługi, poziom higieniczno-sanitarny miejscowości z korzystaniem z pomocy lekarskiej włącznie (według: J. Wo jn a r ow ski 1975 , s. 169).

[25] Wieś turystyczna II - (letniskowa, zimowiskowa) będzie jednostką osadnictwa wiejskiego charakteryzującą się odpowiednimi walorami wypoczynkowymi, dobrą dostępnością komunikacyjną, wyposażoną w podstawowe urządzenia bazy żywieniowej i towarzyszącej, umożliwiająca turystom pobyty $\mathrm{w}$ kwaterach prywatnych (według: J. W a rszyńska, A. J a ckowski 1978 , s. 32 ).

[26] Zdrojowisko - patrz hasła [17] i [20].

[27] Zespół (nadmorskich) miejscowości rekreacyjnych - stanowi go kilka miejscowości rekreacyjnych, $\mathrm{z}$ których jedna jest ośrodkiem centralnym zespołu, mieszczącym usługi nadrzędne. Zespół opiera się na hierarchicznej budowie systemu usługowego (według: H. Gur j 2now a 1975 , s. 30 ).

[28] Zespół osadniczy rekreacyjny - to zespół tworzony przez miejscowość o wiodącej funkcji rekreacyjnej (centrum rekreacyjne), ośrodki i miejscowości o istotnym udziale funkcji rekreacyjnych oraz ośrodki turystyczno-krajoznawcze. Centrum rekreacyjne jest miejscowością wiodącą w ramach zespołu rekreacyjnego, pełniącą centralne funkcje obsługi rekreacji na obszarze mikrorejonu rekreacyjnego (według: A. R o$\mathrm{m}$ is zew ski 1983 , s. 85 ).

[29] Zimowisko - patrz hasła [9] i [25]. podstawq rozwoju uzdrowiskowego, „Problemy Uzdrowiskowe", nr 5-6. 
Dębski L. A., 1974, Nadmorskie aglomeracje wczasowe, Warszawa.

Dę bski L. A., 1975, Górskie osadnictwo wczasowe, Warszawa.

Dę bs k i L. A., 1977, Nadjeziorne ośrodki wczasowe, Warszawa.

Drzewiecki M., 1983, Uwagi o zakresie pojęć turystyka, rekreacja, wczasy, wypoczynek, "Przegląd Geograficzny", z. 1.

Fiularski M., 1935, Zagadnienia ruchu turystycznego, Warszawa.

Gurjanowa H., 1975, Nadmorskie miejscowości rekreacyjne, Warszawa.

Jackowski A., 1981, Typologila funkcjonalna miejscowości turystycznych (na przykładzie woj. nowosądeckiego), „Rozprawy habilitacyjne UJ", nr 53, Kraków.

Kosiński W., 1981, Organizacja przestrzenna wypoczynku weekendowego, Warszawa.

Kostrowicki J., 1952, O funkcjach miastotwórczych i typach funkcjonalnych miast, "Przegląd Geograficzny", z. 1-2.

Leszczycki S., 1938, Wytyczne gospodarki uzdrowiskowo-letniskowej w Karpatach, „Komunikaty Studium Turyzmu UJ", z. 12, Kraków.

L e s z c z y c ki S., 1939, Podstawy gospodarki uzdrowiskowo-letniskowej w Karpatach, "Prace Studium Turyzmu UJ", t. 5, Kraków.

Mileska M. I., 1967, Klasyfikacja miejscowości turystycznych, „Ziemia", Warszawa.

Nawratil-Trybowska E., 1938, Wytyczne gospodarki uzdrowiskowo-letniskowej w Niemczech, "Komunikaty Studium Turyzmụ UJ", z. 11, Kraków.

R og a lewski O., 1974, Zagospodarowanie turystyczne, Warszawa.

R o m is ze wski A., 1983, Osadnictwo a rekreacja, Warszawa.

Stachowski J., 1976, Z problematyki turystyki, wypoczynku i sieci osadniczej, "Acta Universitatis N. Copernici", Geografia XII, Torun.

Szuszkiewicz J., Kasperski B., Henclik Z., 1964, Wypoczynek, porównawcze zestawienie używanych nazw, próba systematyzacji pojęć i propozycje mianownictwa na użytek planowania przestrzennego, "Prace Własne IUA", z. 82, Warszawa.

Szuszkiewicz J., 1966, Urządzenia wczasowe, turystyczne $i$ uzdrowiskowe w Polsce, ser. V - Zagadnienia Krajobrazu i Rekreacji, "Materiały i studia MZPPAUiB", Warszawa.

Szuszkiewicz J., Dubaniewicz J., Kowalski J., Tomaszewski M., 1976, Nazewnictwo dla potrzeb osadnictwa i budownictwa rekreacyjnego, "Zeszyty Naukowe Politech. Gd.", nr 246, Architektura 13.

Trześni owska B., 1981, Wieś letniskowa w świetle literatury, „Koszalinskie Studia i Materialy", nr 4.

Warszyńska J. Jackowski A., 1978, Podstawy geografii turyzmu.

Wojnarowski J., 1975, Ksztaftowanie się modelu sadeckiej wsi letniskowej, "Zeszyty Naukowe AWF", nr 10 (Kraków).

Zagadnienia terminologii w geografii turyzmu, Materiały międzynarodowego sympozjum, 1976, "Zeszyty Naukowe UJ", nr 429, Prace Geograficzne, z. 42.

Dr Jan Stachowski

Zakład Ceoyrafii Ekonomicznej

Wpłynęło:

Instytutu Geografii

18 stycznia 1989

Uniwersytetu Mikołaja Kopernika

w Toruniu

ul. Danielewskiego 6

87-100 'I oruń 


\section{RESUME}

La terminologie de la colonisation liée au tourisme, au repos, à la récréation, utilisée par les géographes polonais, s'est formée d'une façon complexe. Sa première source c'était la langue polonaise de tous les jours, dont certaines notions sur la voie de l'évolution naturelle sont devenues appellations des aspects de la colonisation touristique; ce sont, par exemple, les termes: letnisko (villégiature), zdrojowisko (station thérmale ou balnéaire), osadnictwo turystyczne (colonisation touristique). Une autre source c'était la législative, administrative et économique d'où viennent les définitions au caractère des normes juridiques, p. ex., uzdrowisko (station climatique), miejscowość turystyczna (localité touristique), osadnictwo turystyczno-wypoczynkowe (colonisation touristique et de repos). Enfin c'étaient les organisateurs de l'espace (urbanistes et architectes) qui ont été auteurs des notions et des termes et en ont popularisé plusieurs, p. ex., osadnictwo rekreacyjne (colonisation de récréation), jednostka osadnicza zwiqzana z rekreacja (unité de colonisation liée à la récréation).

Les notions se rapportant à la colonisation, vu la diversité de leur provenance, ont formé un riche vocabulaire de terminologie enfermant un grand nombre de termes synonimiques (synonimes) correspondant au nombre assez limité de notions. Les termes actuels sont, pour la plupart, les combinaisons des deux mots, dont le premier identifie la colonie (p. ex., les termes: localité, village, ville, unité de colonisation), le second définit le caractère découlant de la liaison avec le tourisme (p. ex., touristique, de repos, récréatif). Selon $T^{\prime \prime}$ auteur la terminologie de la colonisation touristique est, à présent, maladiroite, inintelligible. Il propose donc aux géographes de l'ordonner. Dans ce but l'auteur postule l'acceptation du système homogène des notions fondamentales, des cadres logiques d'ordonnance. Il suggère un système notionnel et de terminologie, basé sur la notion fondamentale: récréation, principale par rapport aux notions subordonnées, telles que tourisme, loisirs sport, divertissement, etc. et déterminant les genres essentiels de la colonisation liée avec elles. Un tel système, usé dans la pratique quotidienne, doit éliminer les termes logiquement inconvenants, laisser ceux convenables, créer les termes neufs, menant à la classification logiquement cohérente des notions de Ta colonisation de récréation.

Traduit par Lucjan Kowalski

\section{SUMMARY}

The terminology of settlements connected with tourism, rest and recreation used by the Polish geographers is characterized by its complex genesis. Its original source was the colloquial Polish language, with some of its concepts becoming names of tourist settlement projects through a natural evolution. These are such terms as: letnisko (summer resort), zdrojowisko (watering-place), osadnictwo letniskowe (summer settlements). Another source was the administrative-economic legislation, which supplied definitions of legal norms character such as e.g.: uzdrowisko (health resort), miejscowość turystyczna (tourist locality), osadnictwo turystyczno-wypoczynkowe (tourist-recreational settlements). Finally, a major source of such concepts and 
terms was the terminological output of spatial planners (urban planners, architects), who popularized such terms as osadnictwo rekreacyjne (recreational settlements) or jednostka osadnicza zwiqzana z rekreacja (settlement unit connected with recreation).

Differences in systems of basic and word-formation concepts for derivatives of concepts referning to settlements has led to appearance of an abundant terminological dictionary, which is characterized today by a big number of synonymous terms synonyms referring to a relatively limited number of concepts. A vast majority of terms used today are two-word compilations. The first word in such a compilation identifies a settlement (for instance, such terms as locality, village, town, settlement unit), while the other word defines its character ensuing from its links with tourism (for instance, such terms as touristic, recreational).

According to the author, the terminology of settlements in question is highly incorrect for communicative purposes. That is why he suggests that geographers should put it in order. To this end, he suggests that a uniform system of basic concepts and logical frames of their ordering should be accepted. In the author's opinion, it should be a conceptual-terminological system built on the basis of the fundamental concept such as recreation being superior in relation to subordinate concepts of tourism, organized vacation, sport, entertainment, etc., and describing main types of settlements connected with them. Such a system, used in everyday practice, should be eliminating terms logically not corresponding to it leaving those being suitable, generating new ones, and leading to a logically coherent classification of concepts connected with recreational settlements. 